\title{
Acaricidal activity of thymol against larvae of Rhipicephalus microplus (Acari: Ixodidae) under semi-natural conditions
}

\author{
Laryssa Xavier Araújo ${ }^{1}$ Tatiane Pinheiro Lopes Novato ${ }^{2}$ • Viviane Zeringota ${ }^{2}$. \\ Renata Silva Matos ${ }^{3} \cdot$ Tatiane Oliveira Souza Senra ${ }^{2} \cdot$ Ralph Maturano $^{2}$. \\ Márcia Cristina Azevedo Prata $^{4} \cdot$ Erik Daemon $^{1} \cdot$ Caio Márcio Oliveira Monteiro ${ }^{1}$
}

Received: 8 May 2015 / Accepted: 18 May 2015 /Published online: 4 June 2015

(C) Springer-Verlag Berlin Heidelberg 2015

\begin{abstract}
This is the first study to investigate the activity of thymol on Rhipicephalus microplus larvae under semi-natural conditions. For this purpose, tests were conducted in pots with Brachiaria decumbens seedlings containing cattle tick larvae. Thymol, diluted in ethanol $50^{\circ} \mathrm{GL}$, was tested at concentrations of $2.5,5.0,10.0,15.0$, and $20.0 \mathrm{mg} / \mathrm{mL}$, along with the control group treated with the solvent alone. Each treatment was composed of five pots ( 1 pot=a repetition). The experiment was performed in three steps. On the first day, the larvae were applied at the base of the signalgrass. Twenty-four hours later, approximately $25 \mathrm{~mL}$ of the solution was applied with thymol on the top of the vegetation in each pot. The survival of the larvae was measured $24 \mathrm{~h}$ after application of the solutions. Each pot was analyzed individually, and the grass fillets contained larvae were cut with scissors, placed in Petri dishes, and taken to the laboratory to count the number of living larvae. At the highest concentrations $(10,15$, and $20 \mathrm{mg} /$ $\mathrm{mL}$ ), the number of live larvae declined by more than $95 \%$
\end{abstract}

Laryssa Xavier Araújo

laryssa_xa@hotmail.com

1 Programa de Pós-graduação em Ciências Biológicas, Comportamento e Biologia Animal da Universidade Federal de Juiz de Fora, Rua José Lourenço Kelmer, s/n - Campus Universitário, Bairro São Pedro, Juiz de Fora, MG 36036-900, Brazil

2 Programa de Pós-graduação em Ciências Veterinárias da Universidade Federal Rural do Rio de Janeiro, Rodovia BR 465 - Km 7 - Campus Universitário, Zona Rural, Seropédica, RJ 23851-970, Brazil

3 Universidade Estadual Paulista, Avenida 24 A,1515, Rio Claro, SP 13506-900, Brazil

4 Laboratório de Parasitologia - Embrapa Gado de Leite, Juiz de Fora MG - Rua Eugenio do Nascimento, 610 - Dom Bosco, Juiz de Fora, MG 36038330, Brazil in relation to the control group. The lethal concentration $50 \%$ (LC50) and LC90 values were 3.45 and $9.25 \mathrm{mg} / \mathrm{ml}$, respectively. The application of thymol in semi-natural conditions starting concentration of $10 \mathrm{mg} / \mathrm{mL}$ significantly reduced the number of living $R$. microplus larvae.

Keywords Cattle tick $\cdot$ Brachiaria decumbens $\cdot$ Semi-natural conditions $\cdot$ Monoterpene

\section{Introduction}

The cattle tick, Rhipicephalus microplus (Canestrini, 1888) (Acari: Ixodidae), has serious effects on the productivity of cattle herds because this ectoparasite can cause anemia, weight loss, and decreased milk and meat production, and even animal death in large infestations. Additionally, this tick is responsible for the transmission of pathogenic agents such as the protozoa Babesia bovis (Babes, 1888) (Piroplasmida: Babesidae) and Babesia bigemina (Smith \& Kilborne, 1893) (Piroplasma: Babesidae), as well as the bacterium Anaplasma marginale (Jonsson 2006; Andreotti 2010). The losses to breeders also include the expenses for labor and purchase of acaricides and equipment to treat the animals (Furlong et al. 2007; Andreotti 2010). The most recent estimate is that this tick is responsible for total annual losses of over US\$ 3 billion in Brazil alone (Grisi et al. 2014).

The use of synthetic acaricides features a significant contribution to control of this tick species. However, the indiscriminate use of these products without proper technical orientation causes multiple problems: contamination of food (beef and milk products) and the environment; intoxication of animals and humans; and selection of resistant tick populations, thus requiring development of new control methods (Mendes et al. 2008). 
During the entire life cycle of this tick, only about $5 \%$ of the population is found on host animals, with the other $95 \%$ found in the environment in the form of infesting larvae, eggs, and females in the pre-posture or posture periods. This indicates the need for ongoing control programs, because simple application of acaricides on the animals only affects a small percentage of the overall tick population (Pereira and Labruna 2008). Studies carried out in other countries with other tick species have demonstrated good results from applying pyrethroids and organophosphates in pastures, with reduction of up to $90 \%$ infestation in treated areas. According to Labruna (2008), this initiative is worthy of attention in future research, without obviously failing to consider the risks of environmental contamination.

Thymol, a monoterpene found in the essential oils of various plant species, mainly of the genus Lippia (Verbenaceae) (Ntalli et al. 2011), is a substance with potential for this type of application because it has been found to be active against different tick species while having a lesser impact on the environment when compared to commercial acaricides (Isman et al. 2011). Its efficiency on ticks has been demonstrated in vitro against larvae and adult females of $R$. microplus (Novelino et al. 2007; Monteiro et al. 2010; Scoralik et al. 2012); larvae and nymphs of Amblyomma cajennense s.l. (Fabricius, 1787) (Mendes et al. 2011; Senra et al. 2013); larvae, nymphs, and females of Rhipicephalus sanguineus s.l. (Latreille, 1806) (Monteiro et al. 2009; Senra et al. 2013); and larvae of Dermacentor nitens Neumann, 1897 (Daemon et al. 2012).

On the matter of environmental contamination, studies have shown that thymol poses a small risk due to its rapid dissipation and low level of residues (Hu and Coats 2008). In the USA, thymol is approved as a food additive that is safe to human health by the Food and Drug Administration (FDA) (Ji et al. 2005). Studies have shown that application of carvacrol, a monoterpene isomer of thymol, on vegetation infested with ticks was able to significantly reduce the nymph population of Amblyomma americanum (Linnaeus, 1758) and Ixodes scapularis Say, 1821 (Dolan et al. 2009; Jordan et al. 2011). Therefore, the objective of this experiment was to assess the activity of various thymol concentrations on unengorged $R$. microplus larvae, by tests in semi-natural conditions.

\section{Material and methods}

\section{Study location}

The study was carried out at the Arthropod Parasites Laboratory of Juiz de Fora Federal University, Minas Gerais, Brazil.

\section{Origin of the ticks}

The $R$. microplus larvae were obtained by engorged females obtained from artificial infestations on calves maintained at the experimental farm of the Embrapa Cattle Research Unit, located in the municipality of Coronel Pacheco, Minas Gerais, Brazil (Registration in Ethics Committee on Animal Use of Embrapa 11/2013).

Female ticks were washed in distilled water, dried on sheets of paper towel, placed in Petri dishes, and kept within a climate-controlled chamber $\left(27 \pm 1^{\circ} \mathrm{C}\right.$ and relative humidity (RH) $>80 \%$ ) for oviposition. After 15 days, the eggs were weighed into 100-mg aliquots, placed in plastic syringes with the distal end cut, and closed with hydrophilic cotton. The syringes were then maintained under the same temperature and humidity conditions mentioned before. For the experiment, larvae aged 15 days after hatching were used, being selected for the experiment syringes with hatching percentage above $95 \%$.

\section{Obtaining and diluting of the thymol}

Thymol crystals were purchased from Henrifarma Químicos e Farmacêuticos Ltda., with $99.9 \%$ purity degree certificate. Thymol was tested at concentrations of 2.5, 5.0, 10.0, 15.0, and $20.0 \mathrm{mg} / \mathrm{mL}$. The dilution of substances was made according to Scoralik et al. (2012), using ethanol $50 \%$ (50\% ethanol and $50 \%$ distilled water).

\section{Preparation of the pots containing Brachiaria decumbens seedlings}

Plastic pots measuring $25 \mathrm{~cm}$ in height and $26 \mathrm{~cm}$ in diameter were used to plant the signalgrass seedlings. The pots were filled with $20 \mathrm{~kg}$ of soil obtained from pasture areas of the experimental farm of the Embrapa Dairy Cattle Research Unit, located in the municipality of Coronel Pacheco, Minas Gerais, Brazil. Then, approximately six seedlings were planted in each pot.

All the pots were kept in a open area, with direct incidence from rain and sunlight, just outside the Advanced Laboratory of Zoology of Juiz de Fora Federal University, Minas Gerais, Brazil. The pots were watered daily during the period before the experiment, and urea was applied to promote growth of the seedlings. However, 30 days before the start of the experiment, the urea fertilization was interrupted to prevent the presence of residues of this compound, which is toxic to R. microplus (Cunha et al. 2008). The grass plants were also pruned so that only the central part of each pot contained plants, with an average height of $40 \mathrm{~cm}$. 


\section{Experiment}

The pots were prepared and maintained from May to July 2013, and the treatments started in August that year. The entire experiment was carried out in $72 \mathrm{~h}$. On the first day, adhesive tape was affixed around the edges of all the pots to prevent escape of the larvae. Then, the contents (larvae) of a syringe were placed at the base of the grass plants in each of 40 pots.

After $24 \mathrm{~h}$, each pot was examined to observe the migration of larvae for the apex of the leaves of $B$. decumbens. Following, the application of thymol was performed at different concentrations. For each concentration (treatment), five pots were chosen at random. A manual sprayer was used to apply about $25 \mathrm{~mL}$ of the solution on the plants in each pot, directing the spray to the upper part of the plants where the larvae were agglomerated. At the moment of spraying, each pot was taken to an isolated area. After application, the pots were placed in rows outside the laboratory, with $50 \mathrm{~cm}$ between rows (Fig. 1). The solution was applied by the same person in all the pots to prevent any variation in the form of application.

It also formed a control group with the application of ethanol $50 \%$, solvent having low toxicity to larvae of R. microplus (Chagas et al. 2003; Gonçalves et al. 2007). Due to the volatility of thymol, the pots of the control group were kept away from the pots of the treated groups.

The survival of the larvae was determined $24 \mathrm{~h}$ after applying the solutions. Each pot was analyzed individually, and the grass blades that contained larvae were cut with scissors, placed in Petri dishes (Fig. 2a, b), and was taken to the laboratory to count the living larvae with a vacuum pump (Fig. 2c). Larvae that remained immobile or did not respond to stimuli such as exposure to carbon gas were considered dead.

The number of living larvae found in the control group was compared against the numbers in each treatment group. The treatment efficacy was calculated by the following formula: $\%$ efficacy $=\frac{(A-B \times 100)}{A}$, according to Bittencourt et al. (2003), where $A=$ average number of larvae in the control group and $B=$ average number of larvae in each treated group. Probit analysis was used to calculate the lethal concentrations (LC 50 $\%$ and LC $90 \%$ ), with the POLOPC program (Finney 1971).

\section{Results}

The results are presented in Table 1. In the treatments with the highest thymol concentrations $(10.0,15.0$, and $20.0 \mathrm{mg} / \mathrm{mL}$ ), there were on average fewer than 50 living larvae in each treatment, differing significantly $(p<0.05)$ from the control group (on average, 1079) (Table 1). In the treatments with concentrations of 2.5 and $5.0 \mathrm{mg} / \mathrm{mL}$, the average number of live larvae was 631.6 and 483.4 , being statistically similar to the control group $(p>0.05)$.

At the lowest concentrations tested $(2.5$ and $5.0 \mathrm{mg} / \mathrm{mL})$, the efficacy values of the treatments were 41.49 and $55.22 \%$, respectively. In the other treatments, the values were above 95 $\%$, reaching $99 \%$ in the treatment with a concentration of $20.0 \mathrm{mg} / \mathrm{mL}$ (Table 1), and the lethal concentration (LC50 \% and LC90 \%) values of the treatments were 3.45 and $9.25 \mathrm{mg}$ / $\mathrm{mL}$, respectively (Table 2).

\section{Discussion}

Essential oils and their constituents are promising alternatives to the use of synthetic chemical compounds to control plant and animal pests, aiming to diminish the negative effects of synthetic pesticides (Bakkali et al. 2008). The acaricidal activity of thymol, a monoterpene found in essential oil of plants of the families Lamiaceae and Verbenaceae (Pengelly 2004), has already been demonstrated in vitro studies on larvae (Novelino et al. 2007; Scoralik et al. 2012) and engorged
Fig. 1 Pots containing Rhipicephalus microplus larvae, each corresponding to a treatment with a different concentration to thymol $(\mathrm{mg} / \mathrm{mL})$

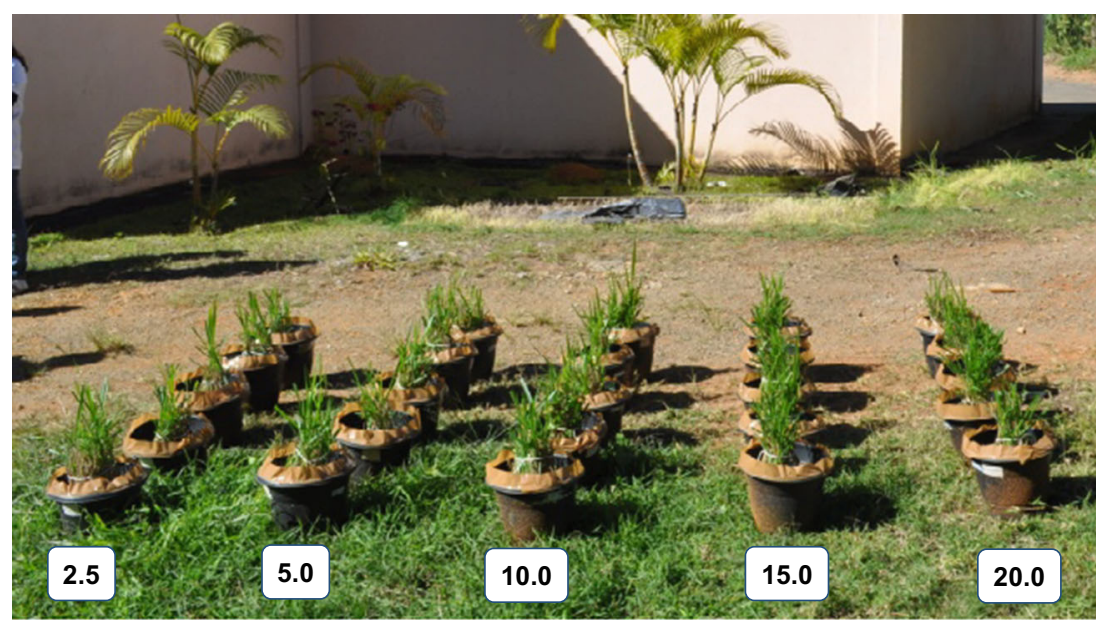


Fig. 2 a Cutting the signalgrass blades containing Rhipicephalus microplus larvae. b Grass blades containing larvae. $\mathbf{c}$ Count the living larvae
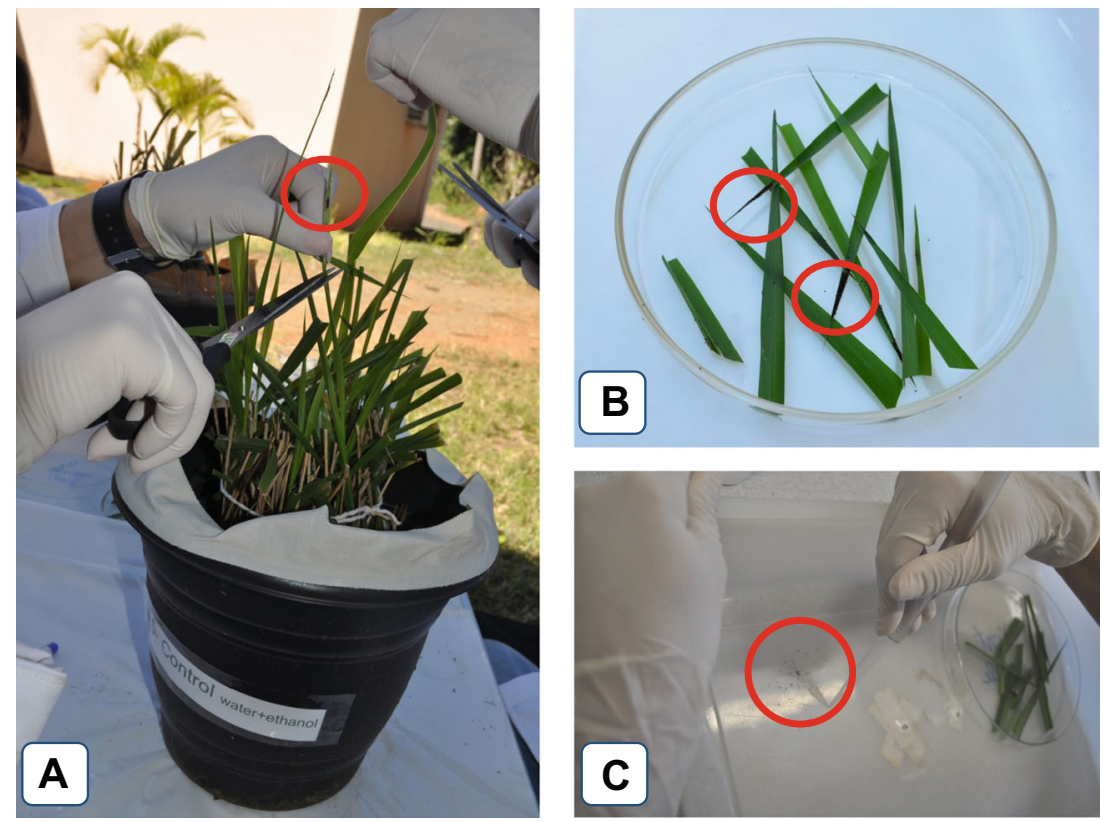

females of $R$. microplus (Monteiro et al. 2010; Matos et al. 2014). However, this article reports the first experiment of the application of thymol in semi-natural conditions.

The mortality observed here was above $95 \%$ starting at a thymol concentration of $10 \mathrm{mg} / \mathrm{mL}$, while in the in vitro study by Scoralik et al. (2012), the same mortality percentage was observed starting at a concentration of $2.5 \mathrm{mg} / \mathrm{mL}$. These differences can be related to the method used and the greater dissipation of thymol in open environments. The experiments of Scoralik et al. (2012) were conducted in controlled laboratory conditions, using the larval packet test, that assures continuous contact of the test organisms with the active ingredient, and the groups were all kept in a climatecontrolled chamber, in contrast to the conditions in this study.

Although no studies have yet been published on application of thymol in the environment to control ticks, this approach has been investigated in studies using carvacrol, a monoterpene isomer of thymol that is also very common in essential oils of plants of the genus Lippia (Botelho et al. 2007; Cavalcanti et al. 2010), results being observed similar to what was found in this study. Dolan et al. (2009) observed $100 \%$ control of nymphs of I. scapularis and A. americanum
1 day after applying carvacrol at a concentration of $5.0 \%$ with a sprayer on a layer of burlap containing these ticks. Seven days after the treatment, the control values for I. scapularis and $A$. americanum decayed to 82.7 and $65.6 \%$, respectively. In another study, Jordan et al. (2011) observed a rapid decline in the population of $I$. scapularis and $A$. americanum nymphs when applying carvacrol at a concentration of $2 \%$ in a pasture, with mortality greater than $90 \% 1$ day after the treatment. However, 14 days after treatment, the mortality rate decayed to $76.7 \%$, so it was necessary to apply the product again. These results reinforce the potential of these compounds to tick control.

Although there have been no studies with ticks, the environmental application of thymol has been investigated for control of other pests. In a study to control the bacterium Ralstonia solanacearum on tomato crops, Ji et al. (2005) reported that thymol at a concentration of $0.7 \%$ reduced the percentage of plants infected by this bacterium to $12 \%$, while in the control group (treated with $70 \%$ ethanol), the infection rate was $65.5 \%$. Besides this, they observed greater tomato yield in the treated plots (increase in both the number and size of fruits). Products based on thymol have also been used with
Table 1 Mean of living Rhipicephalus microplus larvae recovered from the pots treated with thymol at different concentrations and efficacy of the treatments $(\%)($ mean \pm standard deviation)

\begin{tabular}{lll}
\hline Treatments & Mean of living larvae & Efficacy of the treatments (\%) \\
\hline Control (ethanol 50 GL) & $1079.6 \mathrm{a} \pm 514.35$ & \\
Thymol $2.5 \mathrm{mg} / \mathrm{mL}$ & $631.6 \mathrm{a} \pm 229.36$ & 41.49 \\
Thymol $5.0 \mathrm{mg} / \mathrm{mL}$ & $483.4 \mathrm{a} \pm 133.78$ & 55.22 \\
Thymol $10.0 \mathrm{mg} / \mathrm{mL}$ & $41.0 \mathrm{~b} \pm 15.06$ & 96.20 \\
Thymol $15.0 \mathrm{mg} / \mathrm{mL}$ & $49.6 \mathrm{~b} \pm 39.51$ & 95.40 \\
Thymol $20.0 \mathrm{mg} / \mathrm{mL}$ & $1.4 \mathrm{bc} \pm 0.89$ & 99.87 \\
\hline
\end{tabular}

Means followed by different letters in the column differ from each other at $5 \%$ significance 
Table 2 Lethal concentration $50 \%$ (LC50) and $90 \%$ (LC90) of thymol on unengorged larvae of Rhipicephalus microplus kept under seminatural conditions

\begin{tabular}{llll}
\hline LC50 $(\mathrm{mg} / \mathrm{mL})$ & CI $(95 \%)$ & LC90 $(\mathrm{mg} / \mathrm{mL})$ & CI $(95 \%)$ \\
\hline 3.45 & $2.89-4.11$ & 9.25 & $7.71-13.16$ \\
\hline
\end{tabular}

CI confidence interval

high efficacy to control the mite Varroa destructor Anderson \& Trueman, 2000, a parasite of the honeybee Apis mellifera Linnaeus, 1758 (Baggio et al. 2004). Castagnino and Orsi (2012), assessing the effects of thymol alone on colonies of Africanized A. mellifera bees, observed that this substance reduced infestation by $67.1 \%$.

In other countries, studies of the application of synthetic acaricides in the environment to control of other tick species demonstrated that some products of pyrethroids and organophosphates are highly effective (Labruna 2008). Mount et al. (1999) evaluated the application of an acaricide in nonagricultural areas to control the tick $A$. americanum. This method resulted in reductions of 81,76 , and $68 \%$ in the populations of larvae, nymphs, and adults, respectively. When employed together with vegetation reduction, the population declines were 95,92 , and $87 \%$ for larvae, nymphs, and adults. However, the application of pesticides in fields has the drawback of possible environmental contamination. This risk could be minimized by the use of thymol. Miñambres et al. (2010) evaluated the in vitro impact of different thymol doses on the microbial communities in the soil, when applied alone or in combination with a fungicide, and observed that the use of thymol did not significantly alter the microbial activity and biomass, and only posed a risk to the survival of gram-negative bacteria. However, the application of the fungicide in the soil caused a greater reduction in the microbial activity and fungal biomass than thymol. The authors also observed that when the fungicide was mixed with thymol, these negative effects were minimized.

In the USA, the Environmental Protection Agency (EPA) recognizes thymol as a safe compound due to its plant origin, considering that its use in registered pesticides will not cause adverse effects to the environment or human health (Environmental Protection and United States 1993). Hu and Coats (2008) demonstrated that thymol is rapidly dissipated both in water and in soil under aerobic conditions. They measured the time for $50 \%$ to dissipate TD50 in these two environments and observed that in water, the TD50 was 16 days while in soil, it was only 5 days, with volatilization being the main dissipation route.

According to Isman et al. (2011), with rare exceptions, essential oils and their main constituents are relatively nontoxic to mammals, with acute oral LD50 values in rodents between 800 and $3000 \mathrm{mg} \mathrm{kg}^{-1}$ for pure compounds and $5000 \mathrm{mg} \mathrm{kg}^{-1}$ for formulated products. Besides this, due to their volatility, oils and their constituents are generally not environmentally persistent.

In the present study, thymol was applied on the apex of the forage grass, a method that can minimize the possibility of environmental impacts even more. In this context, the application on this layer of vegetation would be aimed to combat infesting larvae, whose natural behavior of climbing to the apex would bring them into contact with the substance. With regard to environmental impacts, this type of application presents as a favorable aspect; the fact reduces the chance of the substance causing some kind of interference on beneficial organisms on the basis of vegetation and soil. Furthermore, the application in the apex of the forage grass can make it easier to implement this method in management programs of this and other tick species.

This method can also reduce infestation of cattle due to the alteration of the larvae's behavior, since an in vitro test demonstrated that thymol also acts as a repellent on this stage of R. microplus (Novelino et al. 2007). Therefore, application at the apex of the vegetation can kill the larvae concentrated there (as indicated in this study) and repel the larvae that are still at the base of the vegetation.

The results obtained in this study show that thymol when applied on $B$. decumbens under semi-natural conditions, in concentrations starting at $10 \mathrm{mg} / \mathrm{mL}$, is effective on R. microplus larvae, significantly reducing the number of larvae. These results further emphasize the potential of thymol as an alternative for control of ticks. However, further studies are necessary under natural conditions to assess the effect of this substance on non-target organisms in pastures and to verify the residual action of this monoterpene.

\section{References}

Andreotti R (2010) Situação atual da resistência do carrapato-do-boi Rhipicephalus (Boophilus) microplus aos acaricidas no Brasil. Campo Grande, MS: Embrapa Gado de Corte, 36 p. http:// www.infoteca.cnptia.embrapa.br/handle/doc/871264. Accessed 30 Jan 2015

Baggio A, Arculeo P, Nanetti A, Marinelli E, Mutinelli F (2004) Field trials with different Thymol-based products for the control of Varroosis. Am Bee J 395-400

Bakkali F, Averbeck S, Averbeck D, Idaomar M (2008) Biological effects of essential oils-a review. Food Chem Toxicol 46:446-475

Bittencourt VREP, Bahiense TC, Fernandes EKK, Souza EJ (2003) Avaliação da ação in vivo de Metarhizium anisopliae (Metschnikoff, 1879) Sorokin, 1883 aplicado sobre Brachiaria decumbens infestada com larvas de Boophilus microplus (Canestrini, 1887) (Acari: Ixodidae). Rev Bras Parasitol V 12(1): 38-42

Botelho MA, Nogueira NAP, Bastos GM, Fonseca SGC, Lemos TLG, Matos FJA, Montenegro D, Heukelbach J, Rao VS, Brito GAC 
(2007) Antimicrobial activity of the essential oil from Lippia sidoides, carvacrol and thymol against oral pathogens. Braz J Med Biol Res 40:349-356

Castagnino GLB, Orsi RO (2012) Produtos naturais para o controle do ácaro Varroa destructor em abelhas africanizadas. Pesqui Agropecu Bras 47(6):738-744

Cavalcanti SCH, Niculau ES, Blank AF, Câmara CAG, Araújo IN, Alves PB (2010) Composition and acaricidal activity of Lippia sidoides essential oil against two-spotted spider mite (Tetranychus urticae Koch). Bioresour Technol 101:829-832

Chagas ACS, Leite RC, Furlong J, Prates HT, Passos WM (2003) Sensibilidade do carrapato Boophilus microplus a solventes. Cienc Rural 33(1):109-114

Cunha AP, Bello ACPP, Leite RC, Oliveira PR, Martins JR, Ribeiro ACCL, Domngues LN, Freitas CMV, Bastianetto E, Wanderley RPB, Rosa RCD (2008) Efeito da adubação com ureia em pastagem, sobre Rhipicephalus (Boophilus) microplus (Acari: Ixodidae). Rev Bras Parasitol V 17(1):64-68

Daemon E, Maturano R, Monteiro CMO, Goldner MS, Massonic T (2012) Acaricidal activity of hydroethanolic formulations of thymol against Rhipicephalus sanguineus (Acari: Ixodidae) and Dermacentor nitens (Acari: Ixodidae) larvae. Vet Parasitol 186: $542-545$

Dolan MC, Jordan RA, Schulze TL, Schulze CJ, Manning MC, Ruffolo D, Schmidt JP, Piesman J, Karchesy JJ (2009) Ability of two natural products, nootkatone and carvacrol, to suppress Ixodes scapularis and Amblyomma americanum (Acari: Ixodidae) in a Lyme disease endemic area of New Jersey. J Econ Entomol 102(6):2316-2324

Environmental Protection Agency, United States. 1993. Office of Prevention, Pesticides And Toxic Substances. http://www.epa.gov/ oppsrrd1/REDs/factsheets/3143fact.pdf. Accessed 30 January 2015

Finney DJ (1971) Probit analysis, 3rd edn. Cambridge University Press, London, U.K., p 333

Furlong J, Martins JR, Prata MCA (2007) O carrapato dos bovinos e a resistência: temos o que comemorar? A Hora Veterinária 159:26-32

Gonçalves K, Toigo E, Ascoli B, Poser GV, Ribeiro VLS (2007) Effects of solvents and surfactant agents on the female and larvae of cattle tick Boophilus microplus. Parasitol Res 100:1267-1270

Grisi L, Leite RC, Martins JRS, Barros ATM, Andreotti R, Cançado PHD, León AAP, Pereira JB, Villela HS (2014) Reassessment of the potential economic impact of cattle parasites in Brazil. Braz $\mathrm{J}$ Vet Parasitol 23(2):150-156

$\mathrm{Hu}$ D, Coats J (2008) Evaluation of the environmental fate of thymol and phenethyl propionate in the laboratory. Pest Manag Sci 64:775-779

Isman MB, Miresmailli S, Machial C (2011) Commercial opportunities for pesticides based on plant essential oils in agriculture, industry and consumer products. Phytochem Rev 10:197-204

Ji P, Momol MT, Olson SM, Pradhanang PM (2005) Evaluation of thymol as biofumigant for control of bacterial wilt of tomato under field conditions. Plant Dis 89(5):497-500

Jonsson NN (2006) The productivity effects of cattle tick (Boophilus microplus) infestation on cattle, with particular reference to Bos indicus cattle and their crosses. Vet Parasitol 137:1-10

Jordan RA, Dolan MC, Piesman J, Schulze TL (2011) Suppression of host-seeking Ixodes scapularis and Amblyomma americanum (Acari: Ixodidae) nymphs after dual applications of plant-derived acaricides in New Jersey. J Econ Entomol 104(2):659-664
Labruna MB (2008) Capítulo 5: Combate contra R. (B.) microplus. In: Pereira MC (ed) Rhipicephalus (Boophilus) microplus: Biologia, controle e resistência. MedVet Livros, São Paulo, pp 65-80

Matos RS, Melo DR, Monteiro CMO, Zeringóta V, Senra TOS, Calmon F, Maturano R, Prata MCA, Daemon E (2014) Determination of the susceptibility of unengorged larvae and engorged females of Rhipicephalus microplus (Acari: Ixodidae) to different methods of dissolving thymol. Parasitol Res 113:669-673

Mendes MC, Lima CKP, Pereira JR (2008) Práticas de manejo para o controle do carrapato Rhipicephalus (Boophilus) microplus (Acari: Ixodidae) em propriedades localizadas na região de Pindamonhangaba, Vale do Paraíba, São Paulo. Arquivo Inst Biol 75(3):371-373

Mendes AS, Daemon E, Monteiro CMO, Maturano R, Brito FC, Massoni $\mathrm{T}$ (2011) Acaricidal activity of thymol on larvae and nymphs of Amblyomma cajennense (Acari: Ixodidae). Vet Parasitol 183:136139

Miñambres GG, Conles MY, Lucini EI, Verdenelli RA, Meriles JM, Zygadlo JA (2010) Application of thymol and iprodione to control garlic white rot (Sclerotium cepivorum) and its effect on soil microbial communities. World J Microb Bio 26:161-170

Monteiro CMO, Daemon E, Clemente MA, Rosa LS, Maturano R (2009) Acaricidal efficacy of thymol on engorged nymphs and females of Rhipicephalus sanguineus (Latreille, 1808) (Acari: Ixodidae). Parasitol Res 105:1093-1097

Monteiro CMO, Daemon E, Silva AMR, Maturano R, Amaral C (2010) Acaricide and ovicide activities of thymol on engorged females and eggs of Rhipicephalus (Boophilus) microplus (Acari: Ixodidae). Parasitol Res 106:615-619

Mount GA, Haile DG, Barnard DR, Daniels E (1999) Integrated management strategies for Amblyomma americanum (Acari: Ixodidae) in non-agricultural areas. Exp Appl Acarol 23:827-839

Novelino AMS, Daemon E, Soares GLG (2007) Evaluation of the acaricide effect of thymol, menthol, salicylic acid, and methyl salicylate on Boophilus microplus (Canestrini, 1887) (Acari: Ixodidae) larvae. Parasitol Res 101:809-811

Ntalli NG, Ferrari F, Giannakou I, Menkissoglu-Spiroudi U (2011) Synergistic and antagonistic interactions of terpenes against Meloidogyne incognita and the nematicidal activity of essential oils from seven plants indigenous to Greece. Pest Manag Sci 67:341351

Pengelly A (2004) The constituents of medicinal plants: an introduction to the chemistry and therapeutics of herbal medicine. Segunda edição, Allen \& Unwin, Australia

Pereira MC, Labruna MB (2008) Capítulo 3: Rhipicephalus (Boophilus) microplus. In: Pereira MC (ed) Rhipicephalus (Boophilus) microplus: Biologia, controle e resistência. MedVet Livros, São Paulo, pp 15-56

Scoralik MG, Daemon E, Monteiro CMO, Maturano R (2012) Enhancing the acaricide effect of thymol on larvae of the cattle tick Rhipicephalus microplus (Acari: Ixodidae) by solubilization in ethanol. Parasitol Res 110:645-648

Senra TOS, Zeringota V, Monteiro CMO, Calmon F, Maturano R, Gomes GA, Faza A, Carvalho MG, Daemon E (2013) Assessment of the acaricidal activity of carvacrol, (E)-cinnamaldehyde, trans-anethole, and linalool on larvae of Rhipicephalus microplus and Dermacentor nitens (Acari: Ixodidae). Parasitol Res 112(4):1461-1466 